\title{
Pro Bono: What's in it for Law Students?
}

So what exactly does make the experience of Pro Bono so special? For me it offers two main benefits to students. Firstly it gives students the skills and confidence necessary to pursue a career in law, and secondly it instills student with a sense of social awareness, professionalism and empathy, which are all essential to becoming a good lawyer.

The skills developed in Pro Bono legal practice are invaluable to the pursuit of a career as a practicing lawyer. Almost every role within the front line services of the legal profession requires basic abilities in client and case management. The focus on techniques such as interviewing, legal writing, organisation, and management of the expectations of client qualify students perfectly to move forward in their legal career. Not only does the development of such skills help undoubtedly benefit students going into practice, but in my own experience provides the confidence to embark on that course. I for one can say that prior to my experience in Pro Bono legal work certainly wasn't confident in pursuing a career as a lawyer. However in developing these skills and confidence, and engaging in first hand experience working as a trainee solicitor, albeit in a Pro Bono setting, verified the enjoyable and exciting nature a career as a lawyer presents.

Not only does Pro Bono develop the basic skills necessary for a lawyer, it also helps to nurture lawyers who uphold the professional and respected image of 
the legal profession. Lawyers not only need to be good at achieving results for their clients, but also at providing a professional and comforting service. Clients that students experience in Pro Bono work tend to come from a variety of social backgrounds This helps to break down any unconscious social bias they may have, to ensure that in practice they approach each case with an open mind and with the necessary social awareness and empathy required of a lawyer. Working in Pro Bono work prior to going in practice helps students to develop as lawyers whose primary concern is to help their clients rather than being purely motivated by money and career advancement. From my own experience work carried out in a Pro Bono setting was extremely rewarding, and confirmed to me why I chose to pursue a career in law.

Students are also given the opportunity to experience exactly what working as a lawyer entails, working within a firm of their own, being assigned other students to work with as partners, and a supervisor to report to. This is another invaluable part of the experience, as the ability to work within a team of lawyers is often what a career in the law involves. On the whole the experience of working in Pro Bono provides students with the necessary skills, and develops the character that is essential for work as a lawyer, while also allowing them to conclude on what form of legal career would suit them most.

\section{Callum Bland}

